\title{
Changes in Teaching Efficacy Beliefs among Elementary Preservice Teachers from a STEM-focused Program: Case Study Analysis
}

\author{
Margareta Maria Thomson, Daniell DiFrancesca, Sarah Carrier, Carrie Lee and Temple A. \\ Walkowiak \\ North Carolina State University, Lawrence University and East Carolina University
}

\begin{abstract}
Four case studies of preservice teachers enrolled in a STEM-focused elementary teacher preparation program are used to document changes in mathematics and science teaching efficacy over the course of one academic year. Qualitative analysis revealed that all four case studies experienced changes in their mathematics and science teaching efficacy beliefs over the course of the year. Participants described unique ways of understanding their growth (or lack thereof) in teaching efficacy, the trajectory of teaching efficacy over the course of the year, and the role of teacher training in changing their efficacy beliefs.
\end{abstract}

Keywords: efficacy beliefs; preservice teachers; STEM education

\section{INTRODUCTION}

In mathematics and science teaching at the elementary level, research shows that most teachers are not adequately prepared to teach mathematics and science (Sharp et al., 2011) and often, they hold negative views towards teaching mathematics and science (Borko \& Whitcomb, 2008). Additionally, elementary teachers do not feel confident about teaching mathematics and science, and in turn, they often exhibit avoidance behaviors by reducing the duration of mathematics and science teaching in favor of other subjects (Lumpe et al., 2000).

Understanding the role of efficacy beliefs in teachers' practices, as well as changes in teachers' efficacy, will help teacher education programs determine the types of academic experiences that are necessary to prepare elementary teachers for their careers. This study responds to the need for more research exploring teachers' changes in mathematics and science efficacy, since teacher efficacy is a key predictor of student achievement (Richardson \& Liang, 2008).

The aim of this study was to document changes in elementary preservice teachers' mathematics and science efficacy beliefs over one academic year during their professional coursework. We captured participants' reflections on their mathematics and science teaching preparation and their efficacy beliefs through interviews. Contributions from this study can help enhance our understanding about when and how changes in teachers' efficacy occurs during an academic year.

\section{Science Teaching Efficacy Beliefs}

Science teaching efficacy beliefs is defined in the literature as teachers' beliefs about their ability to teach science (Bleicher, 2007; Velthuis, Fisser, \& Pieters, 2014). The concept of teacher efficacy has two dimensions, namely, the personal science teaching efficacy, which is a teacher's belief in his or her own teaching skills and the ability to deliver effective instruction, and the science teaching outcome expectancy, which is a teacher's belief that 
effective teaching can impact student learning regardless of external factors such as family background, parental influences, or home environment.

Among the key factors identified in the literature to impact preservice teachers' science teaching efficacy, are mastery learning, vicarious experiences, and verbal persuasion, in addition to science coursework, field experiences, support from peers and school administration, or personal factors (Cantrell, Young, \& Moore, 2003; Thomson et al., 2017; Thomson et al., 2019).

Research shows that teacher preparation programs can help improve preservice teachers' science efficacy by providing positive experiences with science learning for preservice teachers, increasing the science content knowledge during teacher preparation programs, and providing opportunities to teach science in elementary classrooms. Science learning experiences are particularly important for improving science teaching self-efficacy if the experiences provide good models for instruction. Teacher preparation programs can provide new, positive science learning experiences for preservice teachers. Science methods courses that include hands-on and constructivist approaches to learning and teaching science have been found to improve efficacy (Bleicher, 2007; Bleicher \& Lindgren, 2005; Setlage, 2000). Additionally, increasing teachers' science content knowledge can increase science teaching efficacy (Swackhamer et al., 2009; Velthuis, Fisser, and Pieters (2014), as can increase the time preservice elementary teachers spend teaching science in elementary classrooms (Cantrell et al., 2003).

\section{Mathematics Teaching Efficacy Beliefs}

Mathematics teaching efficacy focuses on teachers' feelings of effectiveness in mathematics instruction. The concept of mathematics teaching efficacy consists of two dimensions, namely, the personal mathematics teaching efficacy, which are beliefs about one's own abilities to teach mathematics, and the mathematics teaching outcome expectancy, which are beliefs about one's ability to impact student learning despite students' background experiences (Enochs, Smith, \& Huinker, 2000). Key factors identified in the literature to influence preservice teachers' mathematics teaching efficacy, are generally related to mastery learning, vicarious experiences, and verbal persuasion (Charalambous, Philippou, \& Kyriakides, 2008; Charalambous \& Philippou, 2010). Additionally, other factors, such as the mathematics coursework, field experiences, support from peers and school administration, or personal factors are crucial for developing mathematics teaching efficacy (Thomson et al., 2017).

Research shows that teacher preparation programs can improve preservice teachers' mathematics teaching efficacy, by ensuring positive experiences with mathematics learning, increasing the content knowledge in mathematics during teacher preparation programs, and providing multiple opportunities to teach mathematics in elementary classrooms (e.g., Brown, 2012; Swars et al., 2007). Research found that methods courses within preparation programs had a positive impact on preservice teachers' efficacy and on their attitudes towards teaching mathematics (Brown, 2012; Newton et. al., 2012; Swars, et al., 2007; Utley, Moseley, \& Bryant, 2005). Furthermore, Newton et al. (2012) found that preservice teachers with higher content knowledge referred to verbal persuasion (i.e., encouragement, praise) as a common source of efficacy while those with lower content knowledge spoke of vicarious experiences (i.e., learning from others' experiences) as important for their efficacy judgments. 


\section{METHODS}

\section{Participants}

Parker, Morgan, Casey, and Blake (all names are pseudonyms) are the four elementary preservice teachers we selected for documenting changes in efficacy beliefs. The participants were selected from a group of 19 preservice teachers enrolled in a STEM-focused elementary teacher preparation program in the United States. During the freshman and sophomore years, the preservice teachers completed nine courses of STEM content that included one engineering design, three science, and three mathematics courses. During the time of data collection (the junior year), participants completed two full-time semesters of elementary education coursework accompanied with field experiences. The junior-year coursework included: one engineering, two science, and two mathematics methods courses (K-2 and 3-5). Participants completed field-based assignments in their simultaneous K-2 and 3-5 semester-long field experiences. The qualitative data in this study comes from a larger, five-year research project designed to evaluate the outcomes of the elementary teacher preparation program. Participants were very similar in their demographics; all were white females, 19-20 years old, and had very similar grade point averages (GPA). The four preservice teachers' stories were randomly selected from the 19 case studies. The stories presented here, illustrate different pathways that elementary preservice teachers describe related to their science and mathematics teaching efficacy and changes in efficacy beliefs over the course of one academic year.

\section{Data Sources}

During the course of an academic year, the study participants were interviewed on seven occasions. Four of these interviews were paired with course required field-based assignments: two video recorded mathematics lessons; one video recorded STEM lesson; and one science inquiry project. The remaining three interviews, at the beginning, middle, and end of the year, were designed to learn more generally about the participants' beliefs, backgrounds, and knowledge. Each interview was approximately one hour and was recorded with participant consent and later transcribed verbatim. Appendix A presents the measures, timeline, and procedures for data collection during the academic year for the case study participants. Interview data related to participants' teaching efficacy were coded and organized in order to examine participants' teaching efficacy beliefs, and reflections on their professional training.

The interview protocols asked a range of questions about participants' coursework, field experiences, reflections on their K-5 lessons taught, and their beliefs about teaching. From each interview, only the qualitative data related to participants' efficacy beliefs was used for analyses in this study. Data coding was performed in several steps using an inductive process. In the initial stage, each of the four researchers from the research project read the transcribed interviews for a particular case study and coded the data. Then, all coders convened to discuss their coding. Next, via comparative procedures, all the coded pieces were organized and merged into larger categories. Results from the data analysis were presented in a descriptive manner, using a sequential approach to capture changes over time in participants' efficacy beliefs, such as initial beliefs, moments of change in beliefs, and reflection on their yearlong efficacy trajectory.

\section{RESULTS}

Within each case study, we focus on describing participants' initial efficacy beliefs about mathematics and science teaching, then particular moments in their learning and teaching experiences when they became aware of changes in teaching efficacy, and finally, their trajectory of personal efficacy development over the course of the 
academic year. We present each case study here along with a summary of the cross-case study analyses (in Appendix B).

\section{Parker: "I am ready to teach math" \\ Initial efficacy beliefs}

Parker expressed interest in becoming an elementary school teacher mostly because of her own fourth grade teacher. She was a wonderful model for Parker, always excited about teaching and this had a strong influence on Parker's desire to instill this excitement in her future students. Parker's initial views on her mathematics teaching abilities were relatively high; during her Introductory Interview and her Math Cognitive Interview \#1, she felt very confident about her mathematics teaching abilities due to a strong preparation in mathematics and her personal interests: "I know a lot of people are really nervous about it. I feel like it makes more sense like we were just taught. I feel like this is why you do something and I actually am excited about that, so I think it will be good. I am ready to teach math."

In contrast to her views on mathematics teaching, Parker's initial views about her science teaching abilities were low, due to her weak background in science. During her Introductory Interview and her STEM Cognitive Interview she explained that despite the fact that she had courses in science she feels like she's not mastering the science content well: “I didn't take a weather class or certain classes you didn't like have to take ...I am sure I will learn about how to teach like that but like you need to refresh yourself on certain things." Interestingly, she was not aware when she applied to the elementary teacher preparation program that it has a STEM focus, but this lack of awareness did not affect her decision to become an elementary teacher, nor her teaching confidence: “I was not aware that we were like, well we weren't STEM focused whenever I came in, we were math or science strand which I mean doesn't matter to me cause I am a math and science person, more so than a language arts and social studies person. But I didn't like know exactly the requirements coming in."

\section{Moments of changes in efficacy}

After her second teaching experience (she had taught two K-5 lessons at this point in time), during her Math Cognitive Interview \#2, Parker expressed high mathematics teaching confidence. Further, she demonstrated pedagogical and content knowledge about teaching mathematics by describing in detail her lesson goals, tasks, and how and why she used resources. She also reflected on her own teaching abilities in mathematics:

Things went pretty okay. I didn't think it was the best thing ever, but I thought it was pretty okay. Towards the end, going over the process of how you would tell a friend how to get the volume, they [students] were all able to give me a step-by-step process of how they would go about that. So, I feel like that was pretty much what the lesson was about, that part was very successful.

While she had high efficacy for mathematics teaching, she was still holding low efficacy beliefs about science teaching expressed in her second science interview (Field Based Science Inquiry Assignment). She recognized that she holds many common misconceptions about science concepts and has a hard time addressing these lacunas to her students. Parker also recognized that teaching a STEM lesson was more challenging than she expected because of the complexity of the topic, combining mathematics, science, and engineering concepts into one lesson and because of her lack of knowledge depth in this area:

I never actually - we never did engineering type stuff throughout my schooling. Like the first time I ever heard of STEM was actually here; whenever we actually switched over to STEM. So like we never did the 
process where you think something out. You build something. You try to make it better; that was brand new to me. I mean math and stuff like science, everybody pretty much understands those and the technology, maybe we had a couple of classes throughout schooling like about technology but nothing really major.

\section{Reflection on efficacy trajectory}

Describing her trajectory of efficacy development over the academic year, Parker emphasized that she believes she made the most growth in mathematics teaching efficacy compared to science teaching efficacy. By the end of the year, she was still holding low science teaching efficacy beliefs. During the End of Year Interview while reflecting on her current level of confidence for teaching mathematics and science, Parker said:

I feel really confident teaching math. I feel like I have a good understanding of, a better understanding, of how students think and ways to help them to think and how to develop their thinking. So, I feel really confident about how I could go about teaching math in the classroom. Science, I understand, I feel okay about it, but I don't think I truly know how to go about teaching it in the classroom as much as the other, as math I do.

\section{Morgan: "I don't think I know all of it"}

Initial efficacy beliefs

During her first interview, Morgan mentioned that she always wanted to be a teacher. She had experience working with young children during summer camps and teaching her younger brother things she learned in school. Before applying to the elementary education program, Morgan was not aware of the STEM focus. However, once she learned about the STEM focus she felt it enhanced the integrity of the program, which influenced her decision to attend this university. Morgan also felt a stronger interest and competence in her ability to teach mathematics compared to science. Morgan described in her Introductory Interview that she had struggled in mathematics when she was in high school but a special teacher helped her with the material and also instilled a love of mathematics. While she did not experience these positive influences in science, "I was never really very confident in my ability to do science," she still liked science, "...even though I had a harder time in those [science] classes it didn't really make me think oh, I hate science."

Morgan described her college coursework in science content areas as disconnected from her learning, and noted that her experiences in large lecture style classes did not interest her and furthered her disconnection. These coursework experiences seem to affect her teaching confidence leaving her not knowing what to expect for her upcoming teaching assignments in K-5 math and science.

Moments of changes in efficacy

After she taught her first science lesson (the STEM Project), during her STEM Cognitive Interview, Morgan said that she felt less comfortable teaching science at this point, compared to where she was in the beginning of the semester. She attributed this to seeing far fewer science lessons compared to math lessons in her field placement classroom. This seems to be detrimental to her views about science teaching: "We've observed a lot of math lessons but...we really have never observed any science lessons up until this point." The minimal amount of elementary science instruction greatly influenced her beliefs about her efficacy in teaching science. 
Talking about her mathematics teaching experience Morgan said that she enjoyed teaching mathematics, but she felt anxious every time. During her Math Cognitive Interview \#1 she mentioned that her lesson planning and time management needed more attention than she anticipated, "I enjoyed it more than I thought I would. I was really scared at first, well, I went through stages in the few days leading up. I was really nervous and then I was really excited because I know the kids and I know how they would react and stuff but I was also really nervous. It was just the first time I ever taught them all at once and so, but I was really excited after the lesson. I really enjoyed teaching it."

\section{Reflection on efficacy trajectory}

In describing her trajectory of personal efficacy development throughout an academic year, Morgan described feeling confident in teaching at the beginning of the year, but that confidence was rattled as she began to recognize the complexity of teaching. She maintained her strong desire to become a teacher. She explained:

I am more passionate about it now that I know what teachers do, more of what teachers do at least, I don't think I know all of it, and just have more respect in general for teachers. I used to say teaching is so hard, but I had no idea what I was talking about when I said that, so now I feel like I know a lot more but I still want to become a teacher.

At the end of the year, she still described low science teaching efficacy beliefs. In spite of this, as Morgan described in her End of Year Interview, she clearly sees the value in science for elementary students, "It's really important to have science in the curriculum because it's just how everything works, how the world works." She recognized during some of her science teaching experiences that she will have to be a lifelong learner in order to help her students learn science. She acknowledged that teaching science will require her to learn more science content than she thought she needed.

I guess no matter really what grade I teach, before I start a unit or a lesson I'Il have to research it because even with teaching the first graders about Newton's Law of Motion I had to remind myself a lot of things and do a lot of research into that beforehand so I could teach accurately. I feel like I can do it, but I know that like I'll have to look into things beforehand.

After some initial teaching experiences in multiple grades, Morgan's mathematics teaching confidence increased in both lower and upper elementary grades. The actual teaching experiences were important factors for Morgan's efficacy as she learned to attend to student thinking. "I was nervous to teach, since they're so much older than 5 and 6-year-olds and I knew they would have more questions and that scared me a little bit. And then after teaching some more and getting used to them it went up. And then, after my second math lesson, I didn't feel so good about that, so it went down just a little bit, and then it's slowly starting to go back up."

\section{Casey: "I will evoke that confidence" \\ Initial efficacy beliefs}

Casey expressed interest in becoming a teacher since her fourth grade year in elementary school. She feels that she works well with children and takes pride in being recognized for her skills in this area. Casey expressed fond memories of classes during which she had a relationship with the teacher, and she highly valued interaction in her learning experiences. Talking about her efficacy, Casey described a relatively high level of teaching-efficacy in regard to both mathematics and science teaching at the beginning of her professional coursework (junior year). She 
believed that elementary mathematics and science content is basic and therefore will not be difficult to teach. During her Introductory Interview Casey shared:

I think everything at elementary school level I'll be able to teach just because it doesn't progress much further. I don't know if it's like this anymore. It didn't progress much further past long division and I, I enjoyed that, that's so much fun.

\section{Moments of changes in efficacy}

After her first lesson implementation, Casey continued to express a high level of teaching efficacy for mathematics teaching. In the Math Cognitive Interview \#1, Casey stated:

First grade math isn't difficult for people that are, I guess, that aren't in first grade so I felt confident that I knew what I was saying was right. I know I still have a long time to go before that actually has to be perfect so that's something I know I'm still trying to improve on is making sure the delivery is right.

Casey continued to reference the simplicity of the content as an attribution of her confidence. Her confidence was based on her understanding of the content, but she also acknowledged that she has time to continue to improve her delivery. Casey felt that she learned effective teaching strategies in her methods courses, and she shared, "I'Il be able to [teach], as long as I learn the proper approaches here which I know that I will because I already am, then I'Il be able to teach, I feel very confident." However, after her second mathematics lesson Casey's mathematics teaching efficacy seemed to decrease, and she put more reliance on the mentor teacher than her own abilities: "I mean, the good thing is I knew that if I didn't do a great job teaching it that their teacher could really go over a lot the next day so that was a comfort to me." When asked how the lesson went Casey pointed out more changes she would have made compared to her first lesson, and she expressed doubts in her instruction.

Casey described confidence in science teaching after her teaching experience. In her Field Based Science Inquiry Interview, Casey mentioned that she feels more confident to teach science because she feels that she has more competence in this area: "I feel like the more competent you feel teaching science the more confident you're gonna be at what you're doing and I think it relates because I think I'm gonna end up leaving school feeling like I can teach it pretty well and I don't think a lot of teachers have that same opportunity."

\section{Reflection on efficacy trajectory}

In her description of the efficacy trajectory over one year, Casey seemed to maintain a high level of teaching efficacy for both mathematics and science with some decrease in math teaching efficacy when teaching upper grades mathematics. Casey feels that if she knows the content she is to teach, she will be able to teach it to her students in an effective manner.

At the end of the year, she still feels that she can master mathematics teaching better than science teaching: "I've expanded my knowledge since then [beginning of year], and I've learned more complex math; I think I can help, I'Il be able to explain things [in math] because I do know it. But with science, there's some things that I probably won't know." However, she expressed optimism about her ability to learn and she shared that she is aware that she doesn't always have the knowledge, but she knows how to find it: "I have the confidence, I guess, but I don't have the knowledge to back it up all the time, so, and I feel like having that knowledge, that base knowledge is what really helps explain things to the students, so that's definitely something that I know I'm gonna need more of and I know that'll come with time." Furthermore in regards to all teaching, Casey said "I feel like if I go into it confidently I will evoke that confidence and the students will be able to learn." She seems to value content 
knowledge and self-confidence and acknowledges that experience in the classroom will help her increase in both of these areas.

\section{Blake: "I'm going to try" \\ Initial efficacy beliefs}

Blake described herself as a high achieving student throughout her K-12 schooling, always eager to learn and to share her knowledge with others. This was key in her motivation to become a teacher. Initially, Blake expressed anxiety about teaching mathematics, but felt her early learning experiences in the mathematics methods course were helping her relax. She mentioned that previous mathematics teachers had a great influence on her perception of math abilities, but she feels determined to work hard as a teacher to become better: "I was definitely discounted as like not a math student, and teachers kind of gave up on me; not all teachers, but a lot of my high school mathematics, of course, they just wanted to get me through the class. When I become a teacher, I'm going to try to sit down and work through and figure out why it's not clicking and like how everyone learns in different ways, so like one explanation is not gonna be good for every student in the class."

Blake was not positive about her ability to teach science in the beginning of the semester, during her Introductory Interview. At this point, she did not feel prepared to teach science, and stated that while her science methods course had completed "cool experiments", they had not yet "gotten in depth into how you would teach [science]" because it was still early in the course semester. Importantly, Blake did express a desire to learn to teach high quality science lessons to her students in the future.

Moments of changes in efficacy

Blake's first mathematics teaching experience increased her confidence in teaching, “I think [it] made me feel more comfortable especially for a beginning lesson because I knew they wouldn't be able to ask me a question I wouldn't know." This experience, however, opened her eyes to difficult pedagogical decisions beyond content knowledge that she had not previously considered.

During the Math Cognitive Interview \#2, after her second lesson taught, Blake continued to feel confident in her mathematics teaching, but still experienced issues in selecting appropriate strategies and activities for her students. "I didn't realize how much they already knew about volume when I made that lesson plan so I wasn't expecting them to like get everything, but by the end of the class they were really comfortable with word problems and they also knew cubes and the difference between area and volume."

While she was confident in her ability to teach the mathematics lesson she had planned, she was not able to make instructional decisions during the lesson based on her students' prior knowledge and mastery of the content. “Kids who already knew a lot about volume and word problems didn't get as much out of [the lesson] because they didn't have something to challenge them. So, I would've added more challenging aspects to [the lesson] if I were to redo it."

As far as science teaching, Blake's confidence was still low compared to her mathematics teaching. In her Field Based Science Inquiry Interview, after her second science teaching experience, she mentioned that she now feels more comfortable talking about science topics : “I think I became more comfortable with talking about science subjects 'cause science hasn't always been my like best thing and I was kind of scared to teach it, but now I like learning how to do this and like to interview them and figure out what they actually are talking about has given me 
more of a understanding, like a more comfortable, like how to, how I'm gonna approach science as a teacher, I'm not as intimidated by it."

\section{Reflection on efficacy trajectory}

Blake explained that her confidence in teaching had increased while reflecting on her efficacy trajectory over the course of the year. During her initial teaching experiences, Blake was intimidated by the mentor teachers, which was exacerbated by her limited knowledge of content and pedagogy. She stated that, "I became more confident, especially when I can make the connections between our classes [methods courses] and their [mentor teacher] classes."

At the end of her junior year, Blake's math teaching efficacy was still relatively low, which she attributed to her own struggles with math as a student. "It's not that I don't feel confident but I know I need to work on math, like that's something that I'm gonna have to plan extra hard when I start teaching because I was never the best math student." Blake's science teaching efficacy remained low throughout the year. She confessed that she had limited exposure to seeing science taught in the field, which decreased her confidence: "A little bit [observing science lessons]... we'd do a little bit of science at the end [of the day]. It's not as like much science as I've seen in the past classes."

\section{DISCUSSION}

Findings from our study document participants' initial efficacy beliefs, changes in their efficacy beliefs in relationship with their gain in pedagogical and domain knowledge, and the final stage of reflection on their efficacy trajectory over the course of a year.

\section{Summary of Key Findings}

The study data showed that preservice teachers came into the teacher education program with preconceived notions about their teaching abilities. These initial efficacy beliefs about mathematics and science teaching are grounded in participants' K-12 schooling experiences (i.e., positive or negative mathematics and science experiences), their college coursework, and their personal interests. Research investigating preservice teachers' beliefs has shown that individuals enter teacher education programs with some knowledge of what teaching and learning is, due to their previous schooling experiences (Thomson et al., 2012; Thomson \& Palermo, 2014; Saban et al., 2007). Preservice teachers' cognitive schemas about their teaching beliefs have a strong influence on their future teaching activities and classroom decisions (e.g., Cretu, 2017; Löfström \& Poom-Valickis, 2013; Thomson \& Mclntyre, 2013). All four case study participants made references during their interviews to the fact that their K-12 schooling experiences in mathematics and science classrooms influenced to some degree their present mathematics and science teaching efficacy, and their views about instruction. The lack of experience with elementary science influenced the preservice teachers' expectations regarding their abilities to teach science. They had limited models of effective science teaching, which impacted their efficacy for teaching science (Bong \& Skaalvik, 2003; Thomson et al., 2017). In addition, preservice teachers who personally struggled in learning mathematics or science when they were students were influenced by their negative memories of learning science and mathematics (Thomson et al., 2017).

Findings from our study show that the preservice teachers' initial impressions of teaching mathematics and science changed throughout the academic year and their efficacy trajectories were influenced by learning about pedagogical strategies in mathematics and science that did not necessarily align with their K-5 schooling 
experiences. While preservice teachers negotiated the teaching strategies learned in methods courses with their memories (or lack of) of elementary mathematics and science instruction, they found benefit in helping young children learn mathematics and science. The preservice teachers' experiences working in schools combined with their methods courses helped them to begin to see their potential as teachers of STEM (Bandura, 1977; Bong \& Skaalvik, 2003).

Also, study results showed that all participants experienced changes in their efficacy throughout the academic year. These changes occurred typically after a profound learning activity, especially after their teaching experiences. Changes happened when the participants were confronted with novel, challenging, and oftentimes, unexpected tasks. Examples from interviews referred to participants' inability to adapt their teaching based on student feedback during the lesson or the science content for upper grades seemed unexpectedly complex for planning a lesson.

The way each participant described their efficacy trajectory reflected distinctive, personal changes that are a reflection of their personal interests, opportunities to teach, the quality of their field experiences and their expertise in the content. In the current study, each individual expressed unique views about their professional teacher preparation and described different trajectories of their efficacy during the year with different time points in efficacy changes. Most of them entered their professional studies with naïve, perhaps simplistic visions of teaching. However, through lessons learned in methods coursework and field experiences with mentor teachers and elementary students, these views and thus the preservice teachers' feelings of efficacy began to shift. These shifts in thinking often aligned with growth in content knowledge or increased field classroom exposure. All four participants talked about the importance of getting strong academic experiences and solid pedagogical preparation to be able to support students' in-depth understandings of concepts.

International studies show that elementary teachers are required to adopt STEM reform initiatives and prepare their students for the state standardized tests, but most of them feel weak in their STEM preparation and under confident (Hill, Rowan, \& Ball, 2005; Sharp et al., 2011). Sharp and colleagues (2011), in a study of elementary teachers from the UK, showed that most teachers feel unprepared, or have weak content STEM preparation which impeded their daily instructional choices and affected negatively the quality of their teaching.

Limitations

This study took place in the context of a STEM-focused teacher preparation program that is rather selective; that is, most of the preservice teachers enrolled in the program have experienced success in school (but not necessarily in math and science). Therefore, it is important that future research examines the same phenomenon in other contexts and settings.

Implications

There are several implications of this work for teacher preparation programs. First, teacher preparation programs need to structure and tailor activities in mathematics and science that help preservice teachers align their beliefs about how science and mathematics is taught with research-based practices that support quality instruction and reform initiatives (Charalambous \& Philippou, 2010; Velthuis et al., 2014).

Second, since past experiences in mathematics and science learning impact preservice teachers' confidence in teaching these subjects, it seems collaboration between faculty in education and faculty in mathematics and the sciences may be helpful in changing learning experiences for preservice teachers. While these courses are intended 
to focus on deepening an understanding of the content, they also should demonstrate pedagogical strategies that are inquiry-focused or standards-based.

Third, teacher preparation programs should give attention to the field experiences that are offered in conjunction with the methods coursework. As found among our participants, the field experience is an important activity for impacting preservice teachers' confidence to teach. Therefore, alignment between methods coursework and field experiences in terms of the advocated practices should be considered. Additionally, ensuring that preservice teachers have opportunities to observe science teaching seems important in impacting efficacy to teach science, in particular.

\section{REFERENCES}

Bandura, A. (1993). Perceived self-efficacy in cognitive development functioning. Educational Psychologist, 28(2), 117-148

Bleicher, R. E. (2007). Nurturing confidence in preservice elementary science teachers. Journal of Science Teacher Education, 18, 841-860.

Bleicher, R. E. \& Lindgren, J. (2005). Success in science learning and preservice teaching self-efficacy. Journal of Science Teacher Education, 16, 205-225.

Bong, M. \& Skaalvik, E.M. (2003). Academic self-concept and self-efficacy: How different are they really? Educational Psychology Review, 15(1), 1-40.

Borko, H., \& Whitcomb, J.A. (2008). Teachers, teaching, and teacher education: Comments on the National Mathematics Advisory Panel's report. Educational Researcher, 37, 565-572.

Brown, A. B. (2012). Non-traditional preservice teachers and their mathematics efficacy beliefs. School Science and Mathematics, 112(3), 191-198.

Cantrell, P., Young, S., \& Moore, A. (2003). Factors affecting science teaching efficacy of preservice elementary teachers. Journal of Science Teacher Education, 14(3), 177-192.

Charalambous, C.Y. \& Philippou, G.N. (2010). Teachers' concerns and efficacy beliefs about implementing a mathematics curriculum reform: integrating two lines of inquiry. Educational Studies in Mathematics, $75(1), 1-21$.

Charalambous, C.Y., Philippou,G.N., \& Kyriakides, L. (2008). Tracing the development of preservice teachers' efficacy beliefs in teaching mathematics during fieldwork. Educational Studies in Mathematics, 67 (2), $125-142$.

Cretu, D. (2017). Hopes and fears of teacher candidates concerning the teaching profession. MATEC Web of Conferences, 121, 1-8. DOI: 10.1051/matecconf/201712112002

Enochs, L. G., Smith, P. L., \& Huinker, D. (2000). Establishing factorial validity of the mathematics teaching efficacy beliefs instrument. School Science and Mathematics, 100(4), 194-202.

Hill, H., Rowan, B. \& Ball, D. B. (2005). Effects of teachers' mathematical knowledge for teaching on student achievement. American Educational Research Journal, 42(2), 371-406.

Lumpe, A. T., Haney, J. J., \& Czerniak, C. M. (2000). Assessing teachers' beliefs about their science teaching context. Journal of Research in Science Teaching, 37 (3), 275-292. 
Löfström, E., \& Poom-Valickis, K. (2013). Beliefs about teaching: Persistent or malleable? A longitudinal study of prospective student teachers' beliefs. Teaching and Teacher Education, 35, 104-113.

Newton,K.J., Leonard,J., Evans, B.R., \& Eastburn, J.A. (2012). Preservice elementary teachers' mathematics content knowledge and teacher efficacy. School Science and Mathematics,112 (5), 289-299.

Richardson, G. M., \& Liang, L.L. (2008). The use of inquiry in the development of preservice teacher efficacy in mathematics and science. Journal of Elementary Science Education, 20 (1), 1-16.

Saban, A., Kocbeker, N. B., \& Saban, A. (2007). Prospective teachers' conceptions of teaching and learning revealed through metaphor analysis. Learning and Instruction, 17, 123-139.

Schunk, D. H., Pintrich, P. R., \& Meece, J. L. (2008). Motivation in education: theory, research, and applications. Upper Saddle River, NJ: Pearson.

Setlage, J. (2000). Understanding the learning cycle: Influences on abilities to embrace the approach by preservice elementary school teachers. Science Teacher Education, 84(1), 43-50.

Sharp, J. G., Hopkin, R., \& Lewthwaite, B. (2011). Teacher perceptions of science in the National Curriculum. International Journal of Science Education, 33(17), 2407-2436.

Swackhamer, L. E., Koellner, K., Basile, C., \& Kimbrough, D. (2009). Increasing the self-efficacy of inservice teachers through content knowledge. Teacher Education Quarterly, 36(2), 63-78.

Swars, S., Hart, L. C., Smith, S. Z., Smith, M., \& Tolar, T. ( 2007). A longitudinal study of elementary pre-service teachers' mathematics beliefs and content knowledge. School Science and Mathematics, 107, 325-335.

Thomson, M. M., Turner, J.E., \& Nietfeld, J. (2012). A typological approach to investigate motivation for teaching and beliefs about teaching of preservice teacher candidates. Teaching and Teacher Education, 28, 324-335.

Thomson, M. M., \& Mclntyre, E. (2013). Teachers' professional goals: An examination of different teachers' typologies with respect to motivations and beliefs about teaching. Teacher Development, 17(4),409-430.

Thomson, M.M. \& Palermo, C. (2014). Preservice teachers' understanding of their professional goal: Case studies from three different typologies. Teaching and Teacher Education,44, 56-68.

Thomson, M.M., DiFrancesca, D., Carrier, S., \& Lee, C. (2017). Teaching efficacy: Exploring relationships between mathematics and science self-efficacy beliefs, PCK and domain knowledge among preservice teachers from the United States. Teacher Development, 21 (1), 1-20.

Thomson, M.M., Huggins, E. \& Williams, W. (2019). Developmental science efficacy trajectories of novice teachers from a STEM-focused program: A longitudinal mixed-methods investigation. Teaching and Teacher Education, 77, 253-265.

Utley, J., Moseley, C., \& Bryant, R. (2005). Relationship between science and mathematics teaching efficacy of preservice elementary teachers. School Science and Mathematics, 105 (2), 82-87.

Velthuis, C., Fisser, P., \& Pieters, J. (2014). Teacher training and preservice primary teachers' self-efficacy for science teaching. Journal of Science Teacher Education, 25, 445-464. 


\section{Appendix A}

Measures, Timeline and Procedures for Data Collection

\section{A. Fall Semester}

1. Introductory Interview was conducted in the early Fall semester at the very beginning of the junior year, capturing initial views on teacher preparation, efficacy beliefs and planned instruction.

2. Math Cognitive Interview \#1 was conducted mid Fall semester after participants' first mathematics lesson; captured participants' reflections on their mathematics teaching.

3. STEM Cognitive Interview conducted mid Fall semester after participants' first STEM lesson (STEM Project) was taught to elementary students; captured participants' reflections on science teaching.

\section{A. Spring Semester}

4. Math Cognitive Interview \#2 was conducted mid Spring semester after participants' second mathematics lesson was taught to analyze the lesson and their mathematics teaching.

5. Field Based Science Inquiry Assignment Interview conducted mid Spring semester after participants' science lesson (Field Based Science Inquiry Assignment) was taught to analyze the course of the lesson and their science teaching.

6. Getting to Know You Interview was conducted at the end of Spring semester to learn more about participants' background.

7. End of Year Interview was conducted at the very end of the junior year, end Spring semester capturing views on teacher preparation, efficacy beliefs, and changes in their thinking during the year. 


\section{Appendix B}

Summary of Cross-Case Study Analysis

\begin{tabular}{|c|c|c|c|}
\hline & $\begin{array}{l}\text { Descriptions of initial efficacy } \\
\text { beliefs before mathematics and } \\
\text { science teaching }\end{array}$ & $\begin{array}{l}\text { Descriptions of particular moments } \\
\text { capturing changes in efficacy beliefs }\end{array}$ & $\begin{array}{l}\text { Descriptions of their trajectory of efficacy } \\
\text { beliefs development over the year }\end{array}$ \\
\hline Parker & $\begin{array}{l}\text { High efficacy for mathematics } \\
\text { teaching ("I am ready to teach } \\
\text { math"); but not very confident } \\
\text { about science teaching ("you need } \\
\text { to refresh yourself on certain } \\
\text { things.") }\end{array}$ & $\begin{array}{l}\text { Moderate mathematics efficacy } \\
\text { beliefs after her first math lesson (“It } \\
\text { wasn't that bad"), and slightly } \\
\text { higher confidence about science } \\
\text { teaching(“lesson went pretty well, } \\
\text { better than math") } \\
\text { Increased mathematics efficacy after } \\
\text { second teaching (“I thought it was } \\
\text { fine. I was okay with it."), and } \\
\text { moderate science efficacy, but } \\
\text { intimidated by students' learning } \\
\text { and responses to her teaching } \\
\text { ("maybe that can be a little bit } \\
\text { intimidating.") }\end{array}$ & $\begin{array}{l}\text { Feels high math efficacy over the course } \\
\text { of the year; starts with very low science } \\
\text { efficacy but slight increase by the end of } \\
\text { the year ("And then, I feel confident } \\
\text { about science but then sometimes I feel } \\
\text { unconfident ...like with English and math } \\
\text { we actually have taught, but with science } \\
\text { we really haven't so I'm not as confident } \\
\text { in that as the other two." }\end{array}$ \\
\hline Morgan & $\begin{array}{l}\text { High efficacy in math teaching } \\
\text { with less comfort in science } \\
\text { instruction. Science courses in } \\
\text { high school and college not as } \\
\text { engaging as math. She described } \\
\text { one high school science course, } \\
\text { "So, mostly it was just very notes } \\
\text { intensive and I was just } \\
\text { memorizing things. "She related } \\
\text { a lot of her feelings of efficacy to } \\
\text { her teachers. "I was never really } \\
\text { very confident in my ability to do } \\
\text { science and in high school my } \\
\text { teachers helped me with math and } \\
\text { so I felt really confident about } \\
\text { that." }\end{array}$ & $\begin{array}{l}\text { Morgan felt confident to teach the } \\
\text { lesson because of her math content } \\
\text { knowledge. She felt satisfaction to } \\
\text { witness student success. "I enjoyed } \\
\text { it more than I thought I would. I was } \\
\text { really scared at first...It was just the } \\
\text { first time I ever taught them all at } \\
\text { once and so but I was really excited } \\
\text { after the lesson." } \\
\text { The teaching experience improved } \\
\text { her teaching science views "I was } \\
\text { just nervous about science just } \\
\text { because I was never that interested } \\
\text { in science but now I think it's one of } \\
\text { my favorite subjects to teach." }\end{array}$ & $\begin{array}{l}\text { Confidence started out high but upon } \\
\text { realization that teaching is much more } \\
\text { complex than expected, her confidence } \\
\text { declined. After the teaching experiences } \\
\text { her confidence is "starting to come } \\
\text { back." In the coming year she looks } \\
\text { forward to learning more about how to } \\
\text { be a good teacher "I really want to learn } \\
\text { is just what it's like to be in a classroom } \\
\text { for a whole year or almost a whole } \\
\text { year." }\end{array}$ \\
\hline Casey & $\begin{array}{l}\text { High efficacy for her ability and } \\
\text { teaching reading and literacy } \\
\text { "And so, I've, it's always been my } \\
\text { favorite, reading and literacy has } \\
\text { been my focus, that's what I'm } \\
\text { most excited to teach and I think it } \\
\text { showed in my grades this } \\
\text { semester." } \\
\text { High efficacy for teaching } \\
\text { mathematics and science based } \\
\text { on belief that the content is at a } \\
\text { basic level in elementary school. } \\
\text { “I think everything at elementary } \\
\text { school level I'Il be able to teach } \\
\text { just because it doesn't progress } \\
\text { much further, I mean, when I was }\end{array}$ & $\begin{array}{l}\text { High efficacy for mathematics } \\
\text { teaching after her first lesson, but } \\
\text { low efficacy for teaching } \\
\text { mathematics due to specific issues } \\
\text { she noticed when reviewing her } \\
\text { lesson. Reliance on mentor teacher } \\
\text { to reteach the content. } \\
\text { "I mean, the good thing is I knew } \\
\text { that if I didn't do a great job teaching } \\
\text { it that their teacher could really go } \\
\text { over a lot the next day but so that } \\
\text { was a comfort to me but also like it's } \\
\text { the first lesson, you want to make } \\
\text { sure they get it because it rests on } \\
\text { you." }\end{array}$ & $\begin{array}{l}\text { Starts with high science teaching } \\
\text { efficacy on same bases that it is on a } \\
\text { basic level. Continues to express high } \\
\text { efficacy for teaching science with her } \\
\text { focus on making learning fun and } \\
\text { activity-based. } \\
\text { Feels that her confidence will continue to } \\
\text { increase as she teaches the same } \\
\text { content multiple times. } \\
\text { “I feel like the more competent you feel } \\
\text { teaching science the more confident } \\
\text { you're gonna be at what you're doing } \\
\text { and I think it relates because I think I'm } \\
\text { gonna end up leaving school feeling like } \\
\text { I can teach it pretty well and I don't think }\end{array}$ \\
\hline
\end{tabular}




\begin{tabular}{|c|c|c|c|}
\hline & $\begin{array}{l}\text { in elementary school. I don't know } \\
\text { if it's like this anymore. It didn't } \\
\text { progress much further past long } \\
\text { division and I, I enjoyed that, } \\
\text { that's so much fun." }\end{array}$ & & $\begin{array}{l}\text { a lot of teachers have that same } \\
\text { opportunity" }\end{array}$ \\
\hline Blake & $\begin{array}{l}\text { Initial beliefs revealed anxiety } \\
\text { about teaching mathematics, but } \\
\text { felt her early learning experiences } \\
\text { in the math methods course were } \\
\text { helping her relax: "I think [it] } \\
\text { made me feel more comfortable } \\
\text { especially for a beginning lesson } \\
\text { cause I knew they wouldn't be } \\
\text { able to ask me a question I } \\
\text { wouldn't know." } \\
\text { Also, lacked confidence about } \\
\text { science teaching in the beginning } \\
\text { and understood science teaching } \\
\text { as engaging. }\end{array}$ & $\begin{array}{l}\text { Mathematics efficacy increased after } \\
\text { second lesson taught, and due to } \\
\text { increased exposure to mathematics } \\
\text { content and pedagogical knowledge. } \\
\text { However, Blake's science teaching } \\
\text { efficacy remained low throughout } \\
\text { the year. She had limited experience } \\
\text { teaching science, which decreased } \\
\text { her confidence. }\end{array}$ & $\begin{array}{l}\text { Blake's math teaching efficacy was } \\
\text { initially low, increased slightly after her } \\
\text { first teaching lesson, but generally } \\
\text { remained low during the year, which she } \\
\text { attributed to her own struggles with } \\
\text { math as a student. Her science teaching } \\
\text { efficacy was constantly perceived as } \\
\text { lower due to her limited experience } \\
\text { teaching science during the year. }\end{array}$ \\
\hline
\end{tabular}

\section{Acknowledgements}

The program highlighted in this report was funded by the National Science Foundation (NSF) grant DUNS\#042092122 (Award \#1118894). The study described in this report was initiated and conducted by researchers from a major university in the United States. The results and conclusions reported here are those of the authors and do not necessarily reflect the views of the National Science Foundation.

\section{About the Authors}

Margareta Maria Thomson, Teacher Education and Learning Sciences Department, North Carolina State University Daniell DiFrancesca, Mielke Family Department of Education, Lawrence University

Sarah Carrier, Teacher Education and Learning Sciences Department, North Carolina State University

Carrie Lee, Mathematics, Science, and Instructional Technology Education Department, East Carolina University

Temple A. Walkowiak, Teacher Education and Learning Sciences, North Carolina State University 